\title{
KOMPETENSI KEPALA MADRASAH DALAM PELAKSANAAN DELAPAN STANDAR NASIONAL PENDIDIKAN (SNP)
}

\author{
Asmendri \\ Program Studi Manajemen Pendidikan Islam STAIN Batusangkar \\ Korespondensi: Jl. Green Bariang III E, Anduriang Padang, Sumatera Barat \\ email: asmendri.25@gmail.com
}

\begin{abstract}
The successful implementation on the Eight of Indonesia Nasional Education Standarts at madrasah is determinated by madrasah principal performance. The evaluation of madrasah principal performance need considerate to competencies of a madrasah principal. There are the five competencies of madrasah principal according to Number 13 of 2007 Permendikbud that had by madrasah principal, namely personality competency, managerial, entrepreneurship, supervision, and social.
\end{abstract}

Kata kunci: Kompetensi kepala madrasah, Standar nasional pendidikan, akreditasi madrasah

\section{PENDAHULUAN}

$\mathrm{P}$ endidikan adalah program strategis jangka panjang dalam membangun Sumber Daya Manusia (SDM). Untuk itu perlu mendapat prioritas utama dalam kerangka pembangunan nasional. Setiap negara membuat pembaharuanpembaharuan untuk meningkatkan kualitas pendidikannya. Pembaharuan dalam kebijakan pendidikan merupakan tuntutan dari kebutuhan masyarakat lokal, nasional dan global, juga pengaruh dari pesatnya perkembangan IPTEK. Tuntutan tersebut diantaranya terlihat pada pembaharuan kurikulum, penyusunan standar kualifikasi pendidik, perbaikan manajemen pendidikan, serta pembaharuan sistem pendidikan yang menuntut penghapusan perbedaan antara pendidikan keagamaan dan pendidikan umum. Tuntuntan ini berdampak terhadap perubahan undang-undang yang berkaitan dengan pendidikan.
Pendidikan memegang posisi sentral dalam pembangunan, karena sasarannya adalah meningkatkan kualitas SDM. Ajaran Islam menekankan pentingnya pendidikan dalam kehidupan manusia. Posisi pendidikan terlihat jelas dalam prinsip-prinsip konseptual tentang pendidikan, seperti yang dikemukakan oleh Ismail (2003: 5-7). Pertama, Islam menekankan bahwa pendidikan merupakan perintah kewajiban agama. Seperti perintah yang terdapat dalam ayat 1-5 surat al-Alaq sebagai ayat pertama yang diwahyukan Allah SWT. Nata (2012: 9) juga mengemukakan bahwa "ayat ini memberi isyarat tentang pentingnya pendidikan, yakni; (1) aspek proses dan metodologinya, yaitu mengumpulkan informasi, memahami alam dan sebagainya, (2) aspek guru, dalam hal ini Allah, (3) aspek siswa dalam hal ini Nabi Muhammad SAW, (4) aspek sarana dan prasarana dalam hal ini diwakili dengan kata "pena", dan (5) aspek kurikulum, dalam hal segala sesuatu yang belum 
diketahui manusia". Kedua, seluruh pola rangkaian kegiatan pendidikan dalam konsep Islam merupakan ibadah kepada Allah. Ketiga, Islam memberikan posisi dan derajat yang tinggi kepada orangorang yang terdidik atau berilmu pengetahuan. Keempat, seluruh proses kegiatan pembelajaran dan aktivitas pendidikan dalam konsep dan struktur ajaran Islam berlangsung sepanjang hayat. Kelima, seluruh proses pembelajaran dan pola pendidikan dalam konstruk ajaran Islam adalah bersifat dialogis, inovatif dan terbuka.

Membangun SDM yang sesuai dengan tuntutan masyarakat Indonesia melalui pendidikan melahirkan Undangundang No. 20 tahun 2003 tentang Sistem Pendidikan Nasional. Pada BAB IX pasal 35 ditetapkan 8 (delapan) Standar Nasional Pendidikan (SNP). SNP adalah kriteria minimal tentang sistem pendidikan di seluruh wilayah hukum Negara Kesatuan Republik Indonesia. Undangundang ini diperkuat oleh Pemerintah melalui Peraturan Pemerintah Nomor 19 Tahun 2005 dengan menetapkan SNP yang meliputi standar: (1) isi; (2) proses (3) sarana dan prasarana; (4) tenaga pendidik; (5) penilaian; (6) kompetensi lulusan; (7) pembiayaan dan (8) pengelolaan. SNP memuat kriteria minimal tentang komponen pendidikan yang memungkinkan setiap jenjang dan jalur pendidikan untuk mengembangkan pendidikan secara optimal sesuai dengan karakteristik dan kekhasan programnya.

Sekolah/madrasah (selanjutnya disingkat $\mathrm{S} / \mathrm{M}$ ) sebagai satuan pendidikan memiliki kebebasan dalam melaksanakan proses pendidikan. Kebebasan ini diharapkan bisa meningkatkan mutu pendidikan, karena penekanan suatu kompetensi berbeda-beda sesuai dengan kondisi dimana S/M tersebut berada. Namun setiap S/M tetap diikat oleh SNP agar perbedaan satu satuan pendidikan dengan satuan pendidikan lainnya tidak berada di bawah standar yang sudah ditetapkan.
Pelaksanaan SNP serta pemantauan dan pelaporan pencapaiannya secara nasional dilaksanakan oleh suatu badan standardisasi, penjaminan, dan pengendalian mutu pendidikan. Pencapaian SNP tersebut diukur dalam bentuk akreditasi yang dilakukan oleh satu lembaga pemerintah dan label akreditasi yang diberikan kepada S/M sesuai dengan tingkat pencapaian SNP tersebut.

\section{KOMPETENSI KEPALA MADRA- SAH}

Ketercapaian peringkat akreditasi berkaitan dengan kompetensi kepala madrasah. Kompetensi kepala S/M yang terdapat dalam Permendiknas No. 13 tahun 2007. Ada lima kompetensi (kemampuan atau kecakapan yang diperlihatkan seseorang ketika melakukan sesuatu) yang harus dimiliki kepala S/M yaitu kompetensi kepribadian, manajerial, kewirausahaan, supervisi, dan sosial. Wibowo (2011: 323) mengemukakan bahwa "kompetensi sangat berguna untuk membantu organisasi menciptakan budaya kinerja tinggi, semakin banyak kompetensi dipertimbangkan dalam proses sumber daya manusia akan semakin meningkat budaya organisasi". Implementasi 8 SNP di madrasah tidak hanya ditentukan oleh kompetensi manajerial dan supervisi tetapi didukung juga oleh kompetensi kepribadian, kewirausahaan, dan sosial.

Kompetensi sangat dibutuhkan oleh sebuah lembaga/organisasi untuk menciptakan budaya kinerja tinggi. Menurut Wibowo (2011: 324) kompetensi adalah suatu kemampuan untuk melaksanakan suatu pekerjaan atau tugas yang dilandasi atas keterampilan dan pengetahuan serta didukung oleh sikap kerja yang dituntut oleh pekerjaan tersebut. Sedangkan Spencer dan Spencer (1993) dalam Wibowo (2011: 325) mengemukakan bah-wa kompetensi merupakan landasan da-sar karakteristik orang dan mengiden- 
tifikasikan cara berperilaku atau berpikir, menyamakan situasi, dan mendukung untuk periode waktu cukup lama.

Selanjutnya Wibowo (2011: 325326) mengemukakan lima tipe karakteristik kompetensi, yaitu: 1). motif adalah sesuatu yang secara konsisten dipikirkan atau diinginkan orang yang menyebabkan tindakan; 2). Sifat adalah karakteristik fisik dan respon yang konsisten terhadap situasi atau informasi; 3). Konsep diri adalah sikap, nilai-nilai atau citra diri seseorang; 4). Pengetahuan adalah informasi yang dimiliki orang dalam bidang spesifik; dan 5). Keterampilan adalah kemampuan mengerjakan tugas fisik atau mental tertentu.

\section{MODEL KOMPETENSI}

Model kompetensi menjelaskan perilaku-perilaku yang terpenting yang diperlukan untuk kinerja unggul dalam posisi, peran atau fungsi yang spesifik, yang bisa terdiri dari beberapa atau berbagai kompetensi. Kompetensi kepala S/M yang ditetapkan dalam perundangundangan ada lima, yaitu kompetensi kepribadian, manajerial, supervisi, kewirausahaan, dan sosial.

Terdapat beberapa model kompetensi yang dikemukakan para pakar. Model kompetensi menurut Wibowo (2011: 327-328) dibedakan menurut kepentingannya, sedangkan menurut Zwell (2000: 218) kompetensi dibedakan berdasarkan posisi, tingkat dan fungsi kerja.

Model kompetensi menurut kepentingan dibagi kedalam leadership, coordinator, experts dan support. Model kompetensi untuk empat hal ini pada dasarnya sama dan meliputi: komitmen pada pembelajaran berkelanjutan, orientasi pada pelayanan masyarakat, berpikir konseptual, pengambilan keputusan, mengembangkan orang lain, standar profesionalisme tinggi, dampak dan peng- aruh, inovasi, kepemimpinan, kepedulian organisasi, orientasi pada kinerja, orientasi pada pelayanan, strategi bisnis, kerja sama tim, dan keberagaman.

Sedangkan model kompetensi menurut posisi dapat berupa kepemimpinan pendidikan, manajemen sekolah, kepedulian, dan pelibatan masyarakat, kepemimpinan visioner dan manajemen perubahan, penentuan prioritas, perencanaan dan pengorganisasian, komunikasi, mempengaruhi dan memotivasi, sentivitas antarpribadi dan orientasi pada hasil. Kompetensi menurut tingkat dan fungsi kerja dibedakan menurut supeior dan bukan superior. Kompetensinya berkaitan dengan memengaruhi, mengembangkan orang lain, kerja sama, mengelola kinerja, orientasi pada hasil, perbaikan berkelanjutan, berembangnya inisiatif, membangun fokus dan kepedulian pada kualitas. Kompetensi menurut tingkat dan fungsi kerja, membedakan antara mitra dan superior. Kompe-tensinya berkenaan dengan orientasi pada kewirausahaan, berpikir konseptual, inovasi, berpikir analisis, kualitas keputusan pada pelayanan komunikasi.

\section{TIPE KOMPETENSI}

Tipe kompetensi dikaitkan dengan aspek perilaku manusia dan kemampuannya kenunjukkan kemampuan perilaku tersebut. Wibowo (2011: 328-329) membagi tipe kompetensi tersebut ke dalam 12 tipe, yaitu: Planning competency, influence competency, communication competency, interpersonal competency, thingking competency, organizational competency, human resources management competency, leadership competency, client service competency, business competency, self management competency, dan technical/operational competency. 
Zwell (2000: 25) memberikan lima kategori kompetensi, yang terdiri dari:

1. Task achievement merupakan kategori kompetensi yang berhubungan dengan kinerja baik.

2. Relationship merupakan kategori kompetensi yang berhubungan dengan komunikasi dan bekerja baik dengan orang lain dan memuaskan kebutuhannya.

3. Personal attribute merupakan kompetensi instriksik individu dan menghubungkan bagaimana orang berpikir, merasa, belajar, dan berkembang.

4. Managerial merupakan kompetensi yang secara spesifik berkaitan dengan pengelolaan, pengawasan dan mengembangkan orang.

5. Leadership merupakan kompetensi yang berhubungan dengan memimpin organisasi dan orang untuk mencapai maksud, visi, dan tujuan organisasi.

Spencer dan Spencer (1993) dalam Wibowo (2011:331-332) menyusun kompetensi dalam enam kelompok, yaitu:

1. Achievement dan action, merupakan cluster yang terdiri dari orientasi terhadap prestasi, perhatian terhadap order, kualitas dan akurasi, inisiatif dan pencarian informasi.

2. Helping human service. Merupakan kelompok yang terdiri dari pemahaman secara interpersonal dan orientasi terhadap pelayanan pelanggan

3. Impact dan influence, terdiri atas dampak dan pengaruh, kewaspadaan organisasi, dan membangun hubungan baik

4. Managerial, merupakan kelompok kompetensi yang terdiri dari pengembangan orang lain

5. Cognitif, kelompok yang terdiri dari pemikiran analisis, pemikiran konseptual, keahlian teknis/profesional/manajerial
6. Personal efectiviness, merupakan kelompok yang terdiri pengendalian diri, percaya diri, fleksibilitas, komitmen terhadap organisasi.

Setiap kompetensi tampak pada individu pada berbagai tingkatan. Tingkatan kompetensi menurut Spencer dan Spencer (1993) dalam Wibowo (2011: 332-334) dikelompokkan dalam tiga tingkatan, yatu behavior tools, image attribute, dan personal characteristic.

1. Behavioral Tools, terdiri atas knowledge dan skill. Knowledge merupakan informasi yang digunakan dalam bidang tertentu, dan skill merupakan kemampuan untuk melakukan sesuatu yang baik.

2. Image attribute, terdiri atas social role dan self image. Social role merupakan pola perilaku orang yang diperkuat oleh kelompok sosial atau organisasi. Self image merupakan pandangan orang terhadap dirinya sendiri, identitas, kepribadian, dan harga dirinya.

3. Personal characteristic, terdiri atas traits dan motive. Traits merupakan aspek tipikal berperilaku dan motive merupakan apa yang mendorong perilaku seseorang dalam bidang tertentu.

\section{AKREDITASI MADRASAH}

Akreditasi merupakan suatu kegiatan untuk menilai kelayakan program yang diselenggarakan oleh S/M. Dengan akreditasi, S/M dapat mengetahui seberapa baik program $\mathrm{S} / \mathrm{M}$ telah dilaksanakan, dan dapat digunakan sebagai evaluasi untuk meningkatkan manajemen S/M di waktu yang akan datang. Berkaitan dengan hal tersebut, Pemerintah telah menetapkan Badan Akreditasi Nasional Sekolah/Madrasah (BAN-S/M) dengan Peraturan Mendiknas Nomor 29 Tahun 2005. BAN-S/M adalah badan evaluasi mandiri yang menetapkan ke- 
layakan program dan/atau satuan pendidikan jenjang pendidikan dasar dan menengah jalur formal dengan mengacu pada standar nasional pendidikan. Sebagai institusi yang bersifat mandiri di bawah dan bertanggung jawab kepada Mendikbud, BAN-S/M bertugas merumuskan kebijakan operasional, melakukan sosialisasi kebijakan, dan melaksanakan akreditasi S/M. Dalam melaksanakan akreditasi S/M, BAN-S/M dibantu oleh Badan Akreditasi Provinsi S/M (BAP-S/M) yang dibentuk oleh Gubernur, sesuai Peraturan Pemerintah Nomor 19 Tahun 2005 tentang Standar Nasional Pendidikan, khususnya Pasal 87 ayat (2). Pelaksanaan akreditasi S/M menggunakan kriteria dan perangkat akreditasi yang mengacu pada 8 (delapan) komponen SNP baik untuk satuan pendidikan S/M (Permendiknas Nomor
11 Tahun 2009), SMP/MTs (Permendiknas Nomor 12 Tahun 2009), SMK/ MAK (Permendiknas Nomor 13 Tahun 2009), maupun SMA/MA (Permendiknas Nomor 52 Tahun 2008).

Seharusnya dengan 8 SNP yang sudah ditetapkan beserta semua kebijakan pemerintah yang menyertainya, semua madrasah bisa memperoleh hasil terbaik (A). Namun pada kenyataannnya, hasil akreditasi madrasah khususnya di Sumatera Barat, mayoritas peringkatnya C dan TT (tidak terakreditasi). Kurang dari setengahnya yang mendapatkan akreditasi A dan B dari berbagai tingkatan madrasah yang telah diakreditasi BAN S/M. Hasil Akreditasi Madrasah di Sumatera Barat pada 2007-2012 sebagai ilustrasi atau kenyataan yang ditemui berdasarkan data-data dapat dilihat pada Tabel 1 berikut ini.

Tabel. 1. Akreditasi Madrasah di Sumatera Barat pada 2007-2012

\begin{tabular}{|c|c|c|c|c|c|c|c|c|c|}
\hline \multirow{2}{*}{$\begin{array}{c}\text { Tingkat } \\
\text { Madrasah }\end{array}$} & \multicolumn{8}{|c|}{ Akreditasi } & \multirow[t]{2}{*}{ Jumlah } \\
\hline & $\mathbf{A}$ & $\%$ & B & $\%$ & $\mathrm{C}$ & $\%$ & TT & $\%$ & \\
\hline MI & 7 & 8,05 & 46 & 52,87 & 24 & 27,59 & 10 & 11,49 & 87 \\
\hline MTs & 12 & 3,57 & 103 & 30,65 & 142 & 42,26 & 79 & 23,51 & 336 \\
\hline MA & 20 & 10,36 & 55 & 28,50 & 72 & 37,31 & 46 & 23,83 & 193 \\
\hline Total & 39 & 6,32 & 204 & 33,06 & 238 & 38,57 & 135 & 21,89 & 617 \\
\hline
\end{tabular}

Sumber: BAN-S/M (diakses 17 Februari 2013).

Pada Tabel 1. terlihat bahwa hanya sedikit madrasah yang mencapai akreditasi A, tingkat MI: 8,05\%, MTs: 3,57\%, dan MA: 10,36\%. Untuk akreditasi B pada tingkat MI sudah baik karena lebih dari separuhnya $(52,87 \%)$ mendapat akreditasi $\mathrm{B}$, namun belum baik untuk tingkat MTs $(30,65 \%)$ dan MA $(28,50 \%)$. Pada kategori $\mathrm{C}$, lebih banyak MTs $(42,26 \%)$ yang masuk kategori ini dibanding MI dan MA. Selain itu, madrasah yang masuk kategori TT masih tergolong tinggi, MI: $11,49 \%$, MTs: $23,51 \%$ dan MA: 23, 83\%. Secara keseluruhan (total), madrasah yang memperoleh akreditasi A di Sumatera Barat hanya $6,32 \%$, akreditasi $\mathrm{B}$ : 33,06\%, akreditasi C: 38, 57 dan TT: $21,89 \%$. Angka-angka ini menunjukkan bahwa belum maksimalnya capaian akreditasi secara umum di Sumatera Barat hingga awal tahun 2013. Sedangkan hasil rapat pleno Badan Akreditasi Provinsi S/M Sumatera Barat tanggal 21 Desember 2013 terhadap 225 madrasah dapat dilihat pada Tabel 2 berikut. 
Tabel. 2. Akreditasi Madrasah di Propinsi Sumatera Barat Tahun 2013

\begin{tabular}{cccccccccc}
\hline Tingkat & \multicolumn{1}{c}{ Akreditasi } & Jumlah \\
\cline { 2 - 10 } Madrasah & A & \% & B & \% & C & \% & TT & \% & \\
\hline MI & 1 & 4 & 16 & 64,00 & 8 & 32,00 & 0 & 0 & 25 \\
\hline MTs & 18 & 12,77 & 56 & 39,72 & 56 & 39,72 & 11 & 7,80 & 141 \\
\hline MA & 6 & 10,17 & 25 & 42,37 & 24 & 40,68 & 4 & 6,78 & 59 \\
\hline Total & $\mathbf{2 5}$ & $\mathbf{1 1 , 1 1}$ & $\mathbf{9 7}$ & $\mathbf{4 3 , 1 1}$ & $\mathbf{8 8}$ & $\mathbf{3 9 , 1 1}$ & $\mathbf{1 5}$ & $\mathbf{6 , 6 7}$ & $\mathbf{2 2 5}$ \\
\hline
\end{tabular}

Sumber: BAP Sumatera Barat -S/M (diakses 16 Januari 2014).

Dari Tabel 2 terlihat bahwa, masih tingginya jumlah madrasah yang terakreditasi C dan TT. Khusus untuk madrasah di Kabupaten Tanah Datar sebagai mitra kerja STAIN Batusangkar capaian akreditasinya dari tahun 20072012 dapat dilihat pada Tabel 3. berikut ini.

Tabel. 3. Akreditasi Madrasah di Kabupaten Tanah Datar pada 2007-2012

\begin{tabular}{cccccccccc}
\hline Tingkat & \multicolumn{8}{c}{ Akreditasi } & Jumlah \\
\cline { 2 - 9 } Madrasah & A & $\mathbf{\%}$ & B & \% & C & \% & TT & \% & \\
\hline MI & - & - & 4 & 66.67 & 2 & 33.33 & - & - & 6 \\
\hline MTs & - & - & 15 & 28.30 & 26 & 49.06 & 12 & 22.64 & 53 \\
\hline MA & 2 & 6.25 & 4 & 12.5 & 15 & 46.87 & 11 & 34.37 & 32 \\
\hline Total & $\mathbf{2}$ & $\mathbf{0 , 0 2}$ & $\mathbf{2 3}$ & $\mathbf{2 5 , 2 7}$ & $\mathbf{4 3}$ & $\mathbf{4 7 , 2 5}$ & $\mathbf{2 3}$ & $\mathbf{2 5 , 2 7}$ & $\mathbf{9 1}$ \\
\hline
\end{tabular}

Sumber: BAN-SM (diakses 17 Februari 2013).

Pada Tabel 3. terlihat untuk tingkat MI dan MTs di madrasah Kabupaten Tanah Datar belum ada yang mencapai akreditasi A. Pada tingkat MA, dari 32 MA hanya 2 madrasah $(6,25 \%)$ yang mencapai akreditasi A. Untuk akreditasi $\mathrm{B}$, hanya sedikit madrasah yang mencapainya, pada tingkat MTs: $28,30 \%$ dan MA: $12,5 \%$. Lebih banyak madrasah yang mendapatkan akreditasi C, MTs: 49,06\% dan MA: 46,87\%. Sedangkan untuk yang TT masih cukup tinggi, MTs: 22, 64\% dan MA: 34,37\%. Secara keseluruhan, hanya $0,02 \%$ madrasah yang mendapat akreditasi A; 25,27\% mendapat akreditasi B; 47,25\% mendapat akreditasi $\mathrm{C}$; dan ada $25,27 \%$ untuk TT.

Akreditasi madrasah menjadi prioritas penting Direktorat Jendral Pendidikan Islam Kementerian Agama RI. Hal ini tertuang dalam Rencana Strategik Pembangunan Pendidikan Islam 2010-2014. Berdasarkan rencana strategik tersebut, pada tahun 2014 seluruh satuan pendidikan dari RA, MI, MTs, dan MA harus sudah terakreditasi minimal B. Ada
4 (empat) rencana strategis madrasah yang telah dan akan dilakukan. Pertama tahun 2011 target 10\%, kedua tahun 2012 $30 \%$, tahun ketiga 2013 mencapai $70 \%$, dan tahun keempat 2014 target 100\% madrasah terakreditasi minimal $50 \%$ dengan mutu B. (Buletin Akreditasi Madrasah Edisi 5. 2013: 3).

Berdasarkan rencana strategik tersebut dimana tahun 2013 target 70\% madrasah terakreditasi A dan B belum tercapai. Pada Tabel 3 terlihat bahwa baru 25,29\% madrasah yang terakreditasi A dan B. Khusus untuk MI dan MTs belum ada yang mencapai akreditasi A. Hasil akreditasi ini memberi gambaran belum terlaksanannya dengan baik 8 SNP yang merupakan dasar penilaian akreditasi madrasah terutama di Kabupaten Tanah Datar. Angka-angka ini memunculkan pertanyaan, bagaimana pelaksanaan 8 SNP pada madrasah di Kabupaten Tanah Datar sehingga? Apa saja kendala dan hambatan dalam pelaksanaannya?, Dari delapan aspek SNP, 
standar manakah yang belum terlaksana dan sulit untuk dipenuhi/dicapai?

Namun demikian capaian A pada tingkat MA yakni; MAN 1 dan MAN 2 Batusangkar menjadi hal yang menarik untuk dicermati. Bagaimana pelaksanaan
8 SNP dimadrasah tersebut sehingga bisa memperoleh akreditasi yang baik. Apalagi jika dilihat capaian akreditasi 2 (dua) MAN ini yang sebelumnya hanya pada peringkat $\mathrm{C}$. Jelasnya bisa dilihat pada Tabel 4 dan 5 berikut ini.

Tabel 4. Akreditasi MAN di Kabupaten Tanah Datar tahun 2007

No. Sekolah/Madrasah Nilai Akreditasi Peringkat Akreditasi Tanggal Penetapan

\begin{tabular}{clccc}
\hline 1 & MAN 2 Batusangkar & 60,63 & $\mathrm{C}$ & 18 Desember 2007 \\
\hline 2 & MAN 1 Batusangkar & 69,42 & $\mathrm{C}$ & 18 Desember 2007 \\
\hline 2 & MAN Sumpur & - & - & - \\
\hline 3 & MAN 3 Batusangkar & 60,33 & $\mathrm{C}$ & 18 Desember 2007 \\
\hline
\end{tabular}

Tabel 5. Akreditasi MAN di Kabupaten Tanahdatar tahun 2012

No. Sekolah/Madrasah Nilai Akreditasi Peringkat Akreditasi Tanggal Penetapan

\begin{tabular}{lllll}
\hline 1 & MAN 2 Batusangkar & 90.35 & $\mathrm{~A}$ & $12 / \mathrm{Nov} / 2012$ \\
\hline 2 & MAN 1 Batusangkar & 86.98 & $\mathrm{~A}$ & $12 / \mathrm{Nov} / 2012$ \\
\hline 2 & MAN Sumpur & 81.16 & $\mathrm{~B}$ & $12 / \mathrm{Nov} / 2012$ \\
\hline 3 & MAN 3 Batusangkar & 73.28 & $\mathrm{~B}$ & $12 / \mathrm{Nov} / 2012$ \\
\hline
\end{tabular}

Akreditasi A yang diperoleh MAN 2 dan MAN 1 Batusangkar bisa menjadi masukan bagi madrasah lain. Bagaimana kepala madrasah melaksanakan 8 SNP sehingga bisa meningkatkan peringkat akreditasi madrasahnya dari $\mathrm{C}$ menjadi A. Peringkat akreditasi yang tinggi akan meningkatkan kepercayaan masyarakat. Bagi orang tua, nilai akreditasi menunjukkan mutu madrasah dan mempengaruhi kepercayaan mereka untuk memasukkan anaknya ke madrasah tersebut. Menurut Hendarman (2013) peringkat akreditasi madrasah menjadi hal penting, karena dengan tingginya nilai akreditasi madrasah maka tingkat kepercayaan masyarakat terhadap madrasah tersebut semakin tinggi, sehingga mereka percaya untuk memasukkan anaknya ke madrasah tersebut.

Berdasarkan data akreditasi di atas sebagai salah satu contoh yang ditemukan di berbagai madrasah di Sumatera Barat dapat dikemukakan bahwa pelaksanaan 8 SNP menjadi dasar penilaian untuk akreditasi madrasah. Dari 8 SNP yang dinilai, aspek manakah yang sulit untuk dicapai bagi madrasah dan apa langkah yang dilakukan oleh kepala madrasah menghadapi hal tersebut? Pertanyaan ini menjadi penting untuk diketahui jawabannya, mengingat banyaknya madrasah yang belum mencapai target akreditasi yang ditetapkan terutama madrasah swasta.

Kendala-kendala pelaksanaan akreditasi madrasah menurut Rohmat Mulyana (Kepala Sub Direktorat Kelembagaan \& Ketua Unit Pelaksana Program Akreditasi Madrasah) ada 3 (tiga) hal. Pertama, kesiapan madrasah untuk diakreditasi. Banyak madrasah yang merasa belum layak diakreditasi, masih baru dan siswa belum banyak. Kedua, kesiapan BAN S/M untuk mengekreditasi madrasah. Cakupan madrasah sangat luas lokasinya, geografisnya berbeda-beda BAN S/M tidak punya asesor yang cukup. Ketiga, berkaitan dengan kuota akreditasi. Kuota berkaitan dengan dana 
dari BAN S/M pusat, aliran dana dari balitbang ke BAN Kemendikbud, kemudian ke BAN S/M yang nanti akan di bagi secara proporsional berdasarkan jumlah sekolah dan madrasah. Ketika satu propinsi jumlah sekolah lebih banyak dari madrasah, maka kuota untuk madrasah menjadi sedikit pertahunnya setelah dibagi secara proporsional (Buletin Akreditasi Madrasah Edisi 5. 2013: 4)

Namun jika dilihat dari keterlaksanaan 8 SNP yang menjadi acuan nilai akreditasi maka bisa diketahui secara spesifik aspek-aspek SNP yang belum tercapai dengan maksimal dan kendala dalam pelaksanaannya. Temuan Raharjo (2012: 511) mengungkapkan bahwa dari 8 SNP, standar yang sulit dicapai adalah standar kompetensi lulusan, ketenagaan, sarana dan prasarana. Kendala yang sering dikemukakan dalam pelaksanaan 8 SNP ini berkaitan dengan standar proses. Beban kerja guru 24 jam seminggu yang dikaitkan dengan sertifikasi memberatkan bagi banyak guru (Nurfaisal, 2012). Di samping itu, kelengkapan administrasi yang harus dibuat berupa kelengkapan perangkat pembelajaran, membuat guru menyusun KTSP Buku II (silabus, RPP dan LKS) dengan teknik "copy paste" memakai perangkat yang sudah ada dari sekolah lain; Syamsuri, 2010; Situmorang, 2006). Pelaksanaan standar isi, ketenagaan, sarana dan prasarana, pembiayaan, pengelolaan, penilaian, mempunyai hubungan yang positif yang besarnya bervariasi terhadap variabel standar proses dan kompetensi lulusan (Raharjo, 2012: 511).

Keterlaksanaan 8 SNP dalam penilaian akreditasi juga didasarkan atas kelengkapan data dan dokumen pada setiap standar. Satuan pendidikan harus mempunyai kelengkapan data dan dokumen sebagai syarat penilaian akreditasi. Dalam teknis pelaksanaannya, salah satu 'masalah besar' bagi satuan pendidikan termasuk madrasah ketika menghadapi akreditasi adalah masalah kelengkapan dokumen. Banyak kepala madrasah yang melaksanakan/meminta "lembur", kepada guru hingga penjaga madrasah untuk mempersiapkan dokumen-dokumen yang nantinya ikut dalam penilaian. Akreditasi tidak hanya menilai dokumen, tetapi juga bukti nyata di lapangan. Saat penilaian akreditasi banyak dokumen yang tidak "sinkron". Sering terjadi perangkat pembelajaran berupa RPP pada standar proses mempunyai identitas yang berbeda dengan identitas madrasah yang dinilai. Atau ada madrasah yang tidak memiliki dokumen yang lengkap saat penilaian dilaksanakan. Hasil akreditasi berdasarkan temuan Soejono (2012) belum menggambarkan kondisi objektif S/M, karena S/M melakukan pengkondisian data-data yang tidak sesuai dengan fakta dan penyambutan yang berlebihan. Hal ini disebabkan karena S/M dalam persiapannya belum optimal dan semua data belum merupakan representasi dari proses manajemen yang baik.

Temuan ini juga sejalan dengan hasil penelitian Thaib (2013) yang dilakukan pada tingkat Madrasah Aliyah (MA). Salah satu problematika yang dihadapi MA sewaktu visitasi dilakukan banyak dilakukan rekayasa. Laboratorium beserta alatnya baru diadakan sewaktu visitasi dilakukan. Kesulitan lain berkaitan dengan menyiapkan semua dokumen yang diperlukan dalam akreditasi. Penyiapan dokumen dengan melibatkan tenaga pendidik dan kependidikan madrasah yang bersangkutan sehingga proses pembelajaran di kelas menjadi terganggu.

Ketidaksiapan dari aspek dokumentasi merupakan masalah utama dari madrasah yang tidak siap diakreditasi. Ketidaklengkapan dokumen berkaitan dengan tertib manajemen di S/M tersebut. Jika aspek-aspek manajemen S/M terlaksana dengan baik, tentu segala hal yang berkaitan dengan kelengkapan data dan dokumen untuk akreditasi tidak 
menjadi masalah lagi. Kemajuan satuan pendidikan sangat ditentukan oleh kualitas kemampuan para pengelola dan penyelenggara pendidikan. Kepala madrasah harus memiliki kemampuan manajerial untuk mengolah berbagai perangkat sehingga tercapai tujuan pendidikan di tempatnya. Jadi faktor manajemen berperan penting dalam maju mundurnya lembaga pendidikan termasuk madrasah. Sallis (2003) dalam Usman 2011: 622) mengemukakan bahwa "sebagian besar rendahnya mutu pendidikan disebabkan oleh buruknya manajemen dan kebijakan pemerintah, karena warga S/M hanyalah pelaksana belaka dari kebijakan yang telah ditetapkan atasannya". Juran dalam Usman (2011:623) berpendapat bahwa masalah mutu, $85 \%$ ditentukan oleh manajemennya, sisanya oleh faktor lain. Banyak hasil kajian juga menunjukkan bahwa perbedaan yang tajam antara S/M yang berprestasi tinggi dengan yang berprestasi rendah dipengaruhi oleh kinerja kepala S/M, terutama pada aspek manajemen.

Keterlaksanaan aspek manajemen ini berkaitan dengan kompetensi manajerial dan supervisi kepala madrasah. Kompetensi manajerial dan supervisi kepala madrasah merupakan bagian dari kompetensi kepala S/M yang terdapat dalam Permendiknas No. 13 tahun 2007. Ada lima kompetensi (kemampuan atau kecakapan yang diperlihatkan seseorang ketika melakukan sesuatu) yang harus dimiliki kepala S/M yaitu kompetensi kepribadian, manajerial, kewirausahaan, supervisi, dan sosial. Wibowo (2011 : 323) mengemukakan bahwa "kompetensi sangat berguna untuk membantu organisasi menciptakan budaya kinerja tinggi, semakin banyak kompetensi dipertimbangkan dalam proses sumber daya manusia akan semakin meningkat budaya organisasi". Implementasi 8 SNP di madrasah tidak hanya ditentukan oleh kom- petensi manajerial dan supervisi tetapi didukung juga oleh kompetensi kepribadian, kewirausahaan, dan sosial.

Berhasilnya MAN 1 dan MAN 2 di Kabupaten Tanah Datar memperoleh peringkat akreditasi A bisa dijadikan contoh bagi madrasah lain. Bagaimana kepala madrasah mengimplementasikan 8 SNP sehingga bisa meningkatkan mutu madrasah yang dipimpinnya. Salah satunya keberhasilan implementasi 8 SNP diukur dengan peringkat akreditasi madrasah, yang meningkat dari $\mathrm{C}$ menjadi $\mathrm{A}$. Bila setiap satuan pendidikan telah dapat mencapai atau melebihi SNP tersebut, maka kualitas pendidikan tersebut dapat dinyatakan tinggi. Bagaimana kepala madrasah mengimplemtasikan setiap standar dari 8 SNP, yang sudah ditetapkan dari tahun 2005. Hambatan yang dihadapi dan upaya yang dilakukan untuk pemenuhan 8 SNP bagi setiap satuan pendidikan, sehingga bisa diketahui standar yang paling sulit untuk dipenuhi. Informasi-informasi ini sangat berguna bagi kemajuan madrasah. Masukan bagi madrasah di kabupaten Tanah Datar yang dijadikan pertimbangan secara kontekstual dan konseptual operasional untuk merumuskan pola pelaksanaan 8 SNP. Bahan rekomendasi kepada STAIN Batusangkar untuk melakukan kerjasama dengan madrasah mitranya dalam pelaksanaan aspek-aspek manajemen sehingga mutu madrasah semakin baik dengan terlaksananya 8 SNP di madrasah seperti yang ditetapkan pemerintah. Juga merupakan bahan perbandingan dan pertimbangan bagi Kemenag Kabupaten Tanah Datar dan Kanwil Kemenag Sumbar dalam membina madrasah untuk meningkatkan kualitas pendidikan dan kompetensi kepala madrasah dalam mengimplementasikan 8 SNP. 


\section{PENUTUP}

Kemajuan satuan pendidikan (madrasah/sekolah) sangat ditentukan oleh kualitas kemampuan para pengelola dan penyelenggara pendidikan dalam pelaksanaan delapan Standar Nasional Pendidikan. Kepala madrasah harus memiliki kemampuan manajerial untuk mengolah berbagai perangkat sehingga tercapai tujuan pendidikan di tempatnya. Kenyataan di madrasah/sekolah ditemukan bahwa sebagian besar rendahnya mutu pendidikan bisa juga disebabkan oleh rendahnya perolehan akreditasi. Hal ini bisa disebabkan oleh buruknya manajemen sekolah dan kebijakan pemerintah. Banyak hasil kajian juga menunjukkan bahwa perbedaan yang

\section{DAFTAR RUJUKAN}

Asmendri, 2012. Teori dan Aplikasi Manajemen Peningkatan Mutu Pendidikan Madrasah/Sekolah. Batusangkar: STAIN Batusangkar Press.

Buletin Akreditasi Madrasah. Edisi 5 tahun 2013. Direktorat Madrasah Ditjen Pendidikan Islam Kementerian Agama RI.

Hendarman. 2013. Tantangan Akreditasi Sekolah/Madrasah. Makalah disampaikan pada TOT Asesor SMA/MA dan SMK yang diselenggarakan oleh Badan Akreditasi NasionalSekolah/Menengah (BANS/M) di Haris Hotel and Convention Center, Festival Citylink, Bandung, 29 September 2013.

Ismail, Faisal. 2003. Masa Depan Pendidikan Islam. Di tengah Kompleksitas Tantangan Modernitas. Jakarta: Bakti Aksara Persada. tajam antara $\mathrm{S} / \mathrm{M}$ yang berprestasi tinggi dengan yang berprestasi rendah dipengaruhi oleh kompetensi kepala Sekolah/Madrasah, terutama pada aspek manajemen. Keberhasilan dalam pelaksanaan delapan SNP di madrasah sangat berkaitan dengan aspek manajerial ini, yaitu dengan kompetensi manajerial dan supervisi kepala madrasah tersebut. Kompetensi manajerial dan supervisi kepala madrasah merupakan bagian dari kompetensi kepala S/M yang terdapat dalam Permendiknas No. 13 tahun 2007. Ada lima kompetensi (kemampuan atau kecakapan yang diperlihatkan seseorang ketika melakukan sesuatu) yang harus dimiliki kepala S/M yaitu kompetensi kepribadian, manajerial, kewirausahaan, supervisi, dan sosial.

Kebijakan dan Pedoman Akreditasi Madrasah/Madrasah 2009. Badan Akreditasi Nasional Madrasah/ Madrasah. Website: http://www.ban-sm.or.id

Nata, Abudin. 2012. Kapita Selekta Pendidikan Islam, Isu-isu Kontemporer tentang Pendidikan Islam. Jakarta: RajaGrafindo Persada.

Nurfaisal. 2012. Isu Kritis Pendidikan dalam Pembelajaran. http://www.riaupos. com/opini. php?act=full\&id $=689 \& \mathrm{~kat}=1 . \mathrm{Di}$ akses 25 Februari 2012

Permendiknas Nomor 13 Tahun 2007 tentang Standar Kepala Sekolah/Madrasah

Peraturan Pemerintah Nomor 19 Tahun 2005 tentang Standar Nasional Pendidikan.

Permendiknas Nomor 29 Tahun 2005 tentang Badan Akreditasi Nasional Madrasah/Madrasah (BAN-S/M) 
Permendiknas Nomor 11, 12 dan 13 Tahun 2009 tentang Pelaksanaan Akreditasi Madrasah/Madrasah Untuk Satuan Pendidikan SD/ MI/SMP/MTs/SMK/MAK

Permendiknas Nomor 52 Tahun 2008) Pelaksanaan Akreditasi Sekolah/ Madrasah untuk Satuan Pendidikan SMA/MA.

Raharjo, Sabar Budi. 2012. Evaluasi Trend Kualitas Pendidikan Di Indonesia. Jurnal Penelitian dan Evaluasi Pendidikan, nomor 2, 2012. Hal 511-532.

Situmorang. Hotben. 2006. Isu Mutakhir. Jurnal Pendidikan Penabur - No.07/Th.V/ Desember 2006.

Spenser, Lyle, M,Jr dan Signe M. Spenser. 1993. Competence at Work. New York: John Wiley \& Sons, Inc

Syamsuri. Istamar. 2010. Peningkatan Kompetensi Guru Untuk Meningkatkan Minat Siswa Pada Bidang MIPA. Makalah disampai- kan dalam Lokakarya MIPAnet 2010, The Indonesian Network of Higher Educations of Mathematics and Nanutal Sciences, tanggal 2627 Juli 2010, di IPB, Bogor.

Thaib, Amin. M. 2013. Peta Mutu MA Indonesai Bagian Barat. (Studi Pemetaan Mutu MA di IBB berdasarkan Hasil Akreditasi Hingga Akhir Oktober 2013. Dan Karakteristik Status, Wilayah dan Program yang diselenggrakan). http://blajakarta.kemenag.go.id/ diakses 2 Februari 2014.

Usman, Husaini. 2011. Manajemen, Teori, Praktik, dan Riset Pendidikan. Edisi 3. Jakarta : Bumi Aksara.

Undang-Undang tahun 2003 tentang Sistem Pendidikan Nasional

Wibowo. 2011. Manajemen Kinerja. Jakarta: Rajawali Press.

Zwell, Michael.2000. Creating a Culture of Competence. New York: John Wiley \& Sons, Inc. 